\title{
Shade level effects on yield and chemical composition of the leaf essential oil of Pothomorphe umbellata (L.) Miquel
}

\author{
Raquel Souza Mattana ${ }^{1}$; Maria Aparecida Ribeiro Vieira ${ }^{1,2}$; José Abramo Marchese ${ }^{3}$; Lin \\ Chau Ming ${ }^{4 * ;}$ Márcia Ortiz Mayo Marques ${ }^{1,2}$ \\ ${ }^{1}$ UNESP/FCA - Programa de Pós-Graduação em Agronomia - Horticultura. \\ IAC/Centro de Pesquisa e Desenvolvimento em Recursos Genéticos Vegetais, C.P. 28 - 13001-970 - Campinas, \\ SP - Brasil. \\ ${ }^{3}$ UTFPR - Lab. de Bioquímica e Fisiologia Vegetal, Via do Conbecimento, km 1 - 85503-390 - Pato Branco, PR - \\ Brasil. \\ ${ }^{4}$ UNESP/FCA - Depto. de Produção Vegetal - Setor Horticultura, C.P. 237 - 18603-970 - Botucatu, SP - \\ Brasil. \\ *Corresponding author <linming@fca.unesp.br>
}

\begin{abstract}
Pothomorphe umbellata (L.) Miquel, is a medicinal species that belong to the Piperaceae family and commonly called "pariparoba" and "caapeba". It grows in regions rich in humus, humidity and under the shade of trees, which contribute for its best growth as it is considered a species sciophyte. The effect of shade on the yield and chemical composition of essential oil of Pothomorphe umbellata (Piperaceae) leaves was evaluated. Nine-month-old seedlings were planted in October 2002 and subjected to three shade levels (30\%, $50 \%, 70 \%$ ) and full sun; the experimental design was in randomized blocks, with four treatments and six replications, in split-plot in time scheme. Two harvests of aerial part were made (05/2003 and 05/2004). Essential oil was extracted by hydrodistillation and chemically analyzed by gas chromatography-mass spectrometry (GC-MS). The highest essential oil yield was observed in the second harvest and plants under $30 \%$ shade. Twenty-six chemical substances were identified, of which trans-nerolidol was predominant.

Key words: Piperaceae, cultivation systems, trans-nerolidol, medicinal plant
\end{abstract}

\section{Efeito de níveis de sombreamento no teor e composição química do óleo essencial de folhas de Pothomorphe umbellata (L.) Miquel}

\begin{abstract}
RESUMO: Pothomorphe umbellata (L.) Miquel é uma espécie medicinal brasileira, pertencente à família Piperaceae e popularmente conhecida como pariparoba e capeba. Desenvolve-se em regiões ricas em húmus, umidade e abaixo das sombras de árvores, que contribuem para seu melhor desenvolvimento, é considerada uma espécie esciófita. Avaliou-se o efeito do sombreamento no teor e composição química do óleo essencial de folhas Pothomorphe umbellata (Piperaceae). Mudas com nove meses foram levadas para campo em outubro de 2002 e submetidas a três níveis de sombreamento $(30 \%, 50 \%, 70 \%)$ e a pleno sol, em delineamento experimental de blocos ao acaso, com quatro tratamentos e seis repetições, no esquema de parcelas subdivididas no tempo. Foram realizadas duas colheitas da parte aérea (05/2003 e 05/2004). O óleo essencial foi extraído por hidrodestilação e sua análise química realizada através de CG-EM. O maior teor de óleo essencial ocorreu na segunda colheita em plantas com $30 \%$ de sombreamento. Foram identificadas 26 substâncias químicas, sendo o trans-nerolidol, majoritário.
\end{abstract}

Palavras-chave: Piperaceae, sistema de cultivo, trans-nerolidol, planta medicinal

\section{Introduction}

In Brazil, two indigenous species of Pothomorphe genus can be found and commonly known as "pariparoba" and "caapeba". Pothomorphe peltata occurs in the Amazon region, whereas $P$. umbellata occurs naturally in subforests and borders of the Atlantic forest in the south and southeast regions of the country and is considered a selective sciophyte species (Mattana et al., 2006). The latter is an official species in Brazilian Pharmacopoeia, and although the utilization of its roots is recommended, its leaves are frequently used for tea, plasters, tinctures, fluid extracts, syrup and clearing syrup (Di Stasi et al., 1989). Mattana et al. (2006) using leaves of $P$. umbellata demonstrated that the main secondary metabolites found in the essential oil are terpenes which represent the class of most abundant components of essential oil. Studies focused on the effect of shade on the production and quality of essential oils of medicinal species in general have shown that each species responds differently, with variations in its essential oil yield and chemical composition, according to the environment ( $\mathrm{Li}$ et al., 1996).

Essential oil yield is strictly related to the studied genus of the medicinal plant physiological aspects, which are influenced by environmental factors; among these, solar radiation is one of the most relevant factors. However, few studies have been carried out emphasizing environmental effects on the yield and chemical 
composition of essential oils from P. umbellata. Environmental factors, e.g. photoperiod, radiation and temperature have strong influence on plant development and the relation between biomass production and essential oil is related to higher radiation and photosynthetic rates of plants (Marchese and Figueira, 2005). However, higher irradiance level in esciophyte plants, like $P$. umbellata, can cause photodegradation of cromopigments, with decreases in of photosynthesis and, consequently, biomass yield (Mattana et al., 2006; Marchese et al., 2008).

The current study aimed to evaluate the effect of shade levels on essential oil yield and chemical composition in $P$. umbellate, in order to provide suitable cultivation of P.umbellata with maximum yield and quality of the essential oil.

\section{Material and Methods}

P. umbellata seeds were collected from Adrianópolis, state of Paraná, Brazil (2439' S, 48 ${ }^{\circ} 60^{\prime}$ $\mathrm{W}, 250 \mathrm{~m}$ ) and sown in polyethylene flats in January 2002. Three months later, seedlings were placed in plastic bags then taken to the field when they were nine months old. Plants were subjected to four different shade levels: $70 \%, 50 \%, 30 \%$, and $0 \%$ (full sun), through commercial polystyrene screens. To verify the level photosynthetically active radiation on the shade levels studied, a portable infra-red gas analyzer (IRGA-LI 6200) was used. The measured intensities were: 1,254; 836; 581; and $285 \mu \mathrm{mol}$ PPFD m $\mathrm{m}^{-2} \mathrm{~s}^{-1}$ which represented the shade levels $0 \%$ (full sun), $30 \%, 50 \%$ and $70 \%$, respectively. The experimental design was in randomized blocks with plots subdivided in time (split-plot design); plots included all four shade levels and sub-plots included two harvestings, with six replications and nine plants per plot, to give a total of 54 plants per treatment. Two harvestings of aerial part were carried out - the first on May/2003 and the second on May/2004. Plant parts (leaves, stems and inflorescences) were separated and the leaves were weighed and dried in ovens at $40^{\circ} \mathrm{C}$ to constant weight.

The essential oil was hydrodestilled using samples of $50 \mathrm{~g}$ of dry leaves per plot which were collected in duplicate and placed in glass flasks containing distilled water. Flasks were set over a homeothermic blanket and coupled to a Clevenger-type apparatus. After $3 \mathrm{~h}$ hydrodistillation, essential oils were collected in $5 \mathrm{~mL}$ amber flasks and kept in refrigerator at $-4^{\circ} \mathrm{C}$. The essential oil yield was calculated relative to the dry matter weight of the leaves used for extraction.

Analysis of the oil was performed using gas chromatography coupled to mass spectrometer (Schimadzu mod QP5000), working at $70 \mathrm{eV}$, with a DB-5 capillary column $(30 \mathrm{~m} \times 0.25 \mathrm{~mm} \times 0.25 \mu \mathrm{m})$, helium as carrier gas $\left(1.7 \mathrm{~mL} \mathrm{~min}^{-1}\right)$, injector at $240^{\circ} \mathrm{C}$, detector at $230^{\circ} \mathrm{C}$, and the following program: $60^{\circ} \mathrm{C}-125^{\circ} \mathrm{C}$ at $6^{\circ} \mathrm{C} /$ minute; $125^{\circ} \mathrm{C}-175^{\circ} \mathrm{C}, 3^{\circ} \mathrm{C} /$ minute; $175^{\circ} \mathrm{C}-240^{\circ} \mathrm{C}, 6^{\circ} \mathrm{C} /$ minute; split 20; flow $1.0 \mathrm{~mL} \mathrm{~min}^{-1}$.
The chemical constituents were identified by comparing their mass spectra with the GC-MS system databank (Nist 62.lib), literature (Mclafferty and Stauffer, 1989) and retention rate (Adams, 1995). The results were subjected to analysis of variance and Tukey test $(p<0.05)$, comparing the means obtained in each treatment, using ANOVA Statistical Program.

\section{Results and Discussion}

The essential oil yield was in the range of $0.2 \%$ to $0.6 \%$ (Table 1), which was lower than other Piperaceae species such as Piper regnellii with $0.6 \%$ (Salatino and Silva, 1975), Piper nigrum, 0.6\%-3\% (Giacometti, 1989) and Piper hispidinervium, 4\% (Nascimento and VilhenaPotiguara, 1999). However, it is within normal parameters if compared to those obtained from $P$. umbellata, which varied from $0.1 \%$ (Martins et al., 1998), $0.2 \%$ (Moraes et al., 1984) to 0.4\% (Luz et al., 1999).

An important factor that may have led to this low yield is the season in which the plant samples were collected (fall and winter) (Table 3), where weather data show lower temperature and rainfall in months when the plants were harvested. The climatic conditions of these seasons favored the low production of essential oil (Kapur et al., 1982). However, there are reports on higher essential oil yield in Cymbopogom citratus under dry and cold climate conditions (Figueiredo et al., 2006). More detailed studies about effects of seasonality on essential oil yield in $P$. umbellata are thus needed.

Studies on essential oil yield conditioned by shade levels have shown that each species responds differently to light intensity, such as Thymus vulgaris (Li et al., 1996) and Matricaria chamomila (Saleh, 1973), with increased essential oil yield when grown under intense light. Anethum graveolens (Halva et al., 1992), Salvia oficinalis (Li et al., 1996) and Pothomorphe umbellata plants gave higher essential oil yield when cultivated under shade.

The effects of shade levels were only significant in the second harvesting, in that the plants subjected to $30 \%$ shade gave the highest essential oil yield $(0.62 \%)$, which was different from plants grown under full sun (Table 1). With regard to harvesting, the second showed the

Table 1 - Percentage of essential oil yield of P. umbellata leaves as affected by levels of shade and harvesting seasons.

\begin{tabular}{lcc}
\hline \multirow{2}{*}{ Level of shade } & \multicolumn{2}{c}{ Essential oil yield } \\
\cline { 2 - 3 } & $1^{\text {st }}$ harvest & $2^{\text {nd }}$ harvest \\
\hline 0 & $0.46 \mathrm{Aa}$ & $0.24 \mathrm{Bb}$ \\
\hline 30 & $0.34 \mathrm{Ab}$ & $0.62 \mathrm{Aa}$ \\
50 & $0.41 \mathrm{Aa}$ & $0.54 \mathrm{ABa}$ \\
70 & $0.37 \mathrm{Aa}$ & $0.47 \mathrm{ABa}$ \\
\hline
\end{tabular}

Averages of same capital letter in the column and lower case in the line do not differ (Tukey, $p<0.05$ ). 
highest essential oil yield values. These results corroborate those of Mattana et al. (2006) for leaf and root biomass of $P$. umbellata plants, which yielded more when subjected to $30 \%$ shade. The present results are also confirmed by those of Marchese et al. (2008), who analyzed the photosynthetic activity of pariparoba plants grown under different irradiance levels and noticed that higher $\mathrm{CO}_{2}$ assimilation rate, as well as higher stomata conductance, occurred at PAR of $835.7 \mu \mathrm{mol} \mathrm{m}^{-2} \mathrm{~s}^{-1}$ ( $30 \%$ shade), indicating interrelation of factors.

The correlation between biomass production and essential oil was reported by Marchese and Figueira (2005), who wrote that the production of essential oil is associated with higher irradiance and higher photosynthetic rate, but high irradiance in esciophytes plants, as $P$. umbellate, usually cause chlorosis and necrosis with the photodegradaton of chromopigments, leading to a reduction of photosynthesis and biomass yield (Marchese et al., 2008). Analysis of P. umbellata essential oil evidenced that shade levels and season of harvesting did not alter its chemical composition as the same substances were present in all treatments, except that their concentration varied (Table 2).

Twenty-six chemical substances were identified in the essential oil. Among them, trans-nerolidol (16.43\%), D-germacrene $(13.63 \%)$, trans-caryophyllene $(10.29 \%)$, Beta-elemene $(8.70 \%)$, caryophyllene oxide $(8.39 \%)$, Alfaselinene $(7.42 \%)$ and spathulenol $(6.63 \%)$ were the major components, to give a total of $71.5 \%$ of substances present in the essential oil (Table 2).

The main chemical substances found in the essential oil of this species were very similar to the chemical composition of the leaf essential oil from $P$. peltata, which was studied by Moraes et al. (2004) and consistes of D-germacrene, nerolidol, alpha-humulene and transcaryophyllene, the latter being the main component

Table 2 - Percentage of main chemical constituents of $P$. umbellata leaves essential oil as affected by levels of shade, as well as Kovats Index calculated $\left(\mathrm{IK}_{\mathrm{C}}\right)$ and from literature $\left(\mathrm{IK}_{\mathrm{L}}\right)$.

\begin{tabular}{|c|c|c|c|c|c|c|c|c|c|c|}
\hline \multirow{2}{*}{ Substance } & \multicolumn{4}{|c|}{$1^{\text {st }}$ harvest } & \multicolumn{4}{|c|}{$2^{\text {nd }}$ harvest } & \multirow{2}{*}{$\mathrm{IK}_{\mathrm{C}}$} & \multirow{2}{*}{$\mathrm{IK}_{\mathrm{L}}$} \\
\hline & $0 \%$ & $30 \%$ & $50 \%$ & $70 \%$ & $0 \%$ & $30 \%$ & $50 \%$ & $70 \%$ & & \\
\hline & \multicolumn{8}{|c|}{ (1) $\%$} & & \\
\hline$\beta$-pinene & 0.76 & 0.71 & 0.44 & 0.39 & 1.37 & 1.27 & 1.28 & 1.08 & $968 *$ & 980 \\
\hline trans-anethole & $\operatorname{tr}$ & 0.62 & - & $\operatorname{tr}$ & 0.37 & 0.37 & $\operatorname{tr}$ & $\operatorname{tr}$ & 1278 & 1283 \\
\hline$\beta$-elemene & 0.67 & 1.03 & 0.96 & 0.85 & 1.74 & 1.99 & 1.66 & 1.79 & 1336 & 1339 \\
\hline$\alpha$-cubebene & 0.73 & 1.03 & 0.84 & 0.85 & 1.18 & 1.27 & 1.12 & 1.20 & 1348 & 1351 \\
\hline$\alpha$-copaene & 1.56 & 1.61 & 1.44 & 1.44 & 2.24 & 2.14 & 1.91 & 1.87 & 1374 & 1376 \\
\hline$\beta$-bourbunene & $\operatorname{tr}$ & $\operatorname{tr}$ & - & $\operatorname{tr}$ & $\operatorname{tr}$ & 0.68 & 0.75 & 0.71 & 1383 & 1384 \\
\hline$\beta$-cubebene & $\operatorname{tr}$ & $\operatorname{tr}$ & - & $\operatorname{tr}$ & $\operatorname{tr}$ & $\operatorname{tr}$ & 0.78 & $\operatorname{tr}$ & 1390 & 1390 \\
\hline$\beta$-elemene & 5.71 & 7.08 & 8.29 & 8.23 & 9.31 & 10.15 & 9.89 & 10.98 & 1394 & 1391 \\
\hline trans-caryophyllene & 8.84 & 8.67 & 8.37 & 8.77 & 12.74 & 11.69 & 11.09 & 11.97 & 1418 & 1418 \\
\hline$\beta$-gurjunene & 0.62 & 0.66 & 0.63 & 0.61 & 0.88 & 1.03 & 0.96 & 0.97 & 1427 & 1432 \\
\hline$\beta$-geranyl acetone & 4.92 & 5.07 & 4.34 & 4.63 & 4.51 & 3.73 & 4.03 & 3.38 & 1447 & 1453 \\
\hline$\alpha$-humulene & 0.68 & 0.62 & 0.63 & 0.62 & 1.08 & 0.94 & 0.91 & 0.96 & 1451 & 1454 \\
\hline$\gamma$-muurolene & 1.11 & 1.16 & - & 0.64 & 1.27 & 1.78 & 1.52 & 1.51 & 1475 & 1477 \\
\hline germacrene-D & 12.67 & 14.64 & 14.26 & 13.18 & 12.27 & 13.27 & 13.35 & 15.40 & 1480 & 1480 \\
\hline$\beta$-selinene & 0.94 & 1.23 & 1.08 & 1.17 & 2.09 & 2.80 & 2.50 & 2.42 & 1483 & 1485 \\
\hline$\alpha$-selineno & 5.07 & 6.32 & 5.32 & 5.35 & 8.15 & 9.89 & 9.27 & 9.98 & 1492 & 1494 \\
\hline$\alpha$-muroleno & - & 0.10 & - & - & - & - & - & $\operatorname{tr}$ & 1494 & 1499 \\
\hline germacrene-A & 0.88 & 0.56 & 1.06 & 0.53 & 0.98 & 0.98 & 1.00 & 1.10 & 1599 & 1509 \\
\hline$\gamma$-cadinene & 1.70 & 1.45 & 1.39 & 3.43 & 1.46 & 1.79 & 1.76 & 1.84 & 1511 & 1513 \\
\hline cis-calamenene & 0.04 & 0.02 & - & - & - & - & - & $\operatorname{tr}$ & 1518 & 1521 \\
\hline$\delta$-cadinene & 1.58 & 2.59 & - & 1.17 & 1.82 & 2.59 & 2.23 & 2.34 & 1520 & 1524 \\
\hline trans-nerolidol & 20.02 & 18.98 & 16.8 & 18.04 & 16.14 & 13.89 & 13.89 & 13.67 & 1562 & 1564 \\
\hline Spathulenol & 10.02 & 8.45 & 9.61 & 9.35 & 4.28 & 3.41 & 4.07 & 3.83 & 1574 & 1576 \\
\hline caryophyllene oxide & 11.08 & 8.52 & 9.92 & 10.71 & 8.01 & 5.81 & 7.02 & 6.08 & 1579 & 1581 \\
\hline epi-alpha-cadinol & 1.47 & 1.47 & 1.61 & 1.83 & 1.02 & 1.51 & 1.83 & 1.54 & 1638 & 1640 \\
\hline Cubenol & 1.07 & 0.98 & 1.184 & 1.31 & 0.64 & 0.81 & 1.10 & 0.85 & 1642 & 1640 \\
\hline Total & 90.59 & 90.72 & 90.06 & 89.53 & 92.47 & 94.16 & 92.60 & 94.32 & & \\
\hline
\end{tabular}


Table 3 - Temperature, precipitation and relative humidity during the period of the experiment.

\begin{tabular}{lccccc}
\hline \multirow{2}{*}{ Date } & \multicolumn{3}{c}{ Temperature } & Precipitation & RH \\
\cline { 2 - 3 } & Minimal & Maxim & Media & mm & $\%$ \\
\hline jul/02 & 12.6 & 22.5 & 15.7 & 40.7 & 74.5 \\
\hline aug/02 & 15.9 & 26.7 & 19.8 & 76.4 & 69.6 \\
\hline sept/02 & 13.9 & 25.3 & 18.2 & 65.1 & 72.0 \\
\hline oct/02 & 18.7 & 31.6 & 24.1 & 52.7 & 69.9 \\
\hline nov/02 & 18.0 & 28.3 & 21.3 & 178.9 & 73.2 \\
\hline dec/02 & 18.8 & 29.3 & 22.4 & 192.0 & 69.4 \\
\hline jan/03 & 19.6 & 27.2 & 22.0 & 412.0 & 75.4 \\
\hline feb/03 & 20.3 & 30.0 & 24.5 & 127.6 & 68.5 \\
\hline mar/03 & 18.7 & 28.0 & 21.7 & 179.8 & 74.8 \\
\hline apr/03 & 17.1 & 26.5 & 21.0 & 293.5 & 73.7 \\
\hline may/03 & 13.4 & 23.3 & 16.8 & 52.9 & 61.5 \\
\hline jun/03 & 14.7 & 25.0 & 18.4 & 23.7 & 61.7 \\
jul/03 & 13.4 & 24.1 & 17.1 & 15.8 & 52.4 \\
\hline aug/03 & 12.0 & 23.4 & 16.4 & 33.9 & 52.0 \\
\hline sept/03 & 14.2 & 26.9 & 18.9 & 14.9 & 48.2 \\
\hline oct/03 & 18.6 & 27.7 & 19.8 & 149.1 & 63.3 \\
\hline nov/03 & 19.2 & 27.0 & 20.1 & 173.5 & 62.1 \\
\hline dec/03 & 18.9 & 28.1 & 21.8 & 183.9 & 68.0 \\
\hline jan/04 & 18.4 & 26.6 & 20.6 & 302.0 & 71.1 \\
\hline feb/04 & 18.3 & 27.8 & 21.4 & 161.6 & 73.0 \\
\hline mar/04 & 17.6 & 27.0 & 20.5 & 122.3 & 67.6 \\
\hline apr/04 & 17.9 & 26.1 & 20.5 & 114.0 & 68.2 \\
\hline may/04 & 13.7 & 21.9 & 15.7 & 133.5 & 68.7 \\
\hline jun/04 & 13.3 & 21.7 & 15.8 & 28.8 & 60.6 \\
\hline jul/04 & 12.7 & 15.1 & 104.3 & 58.2 \\
\hline & & & & \\
\hline
\end{tabular}

(67\%). However, the major substance found in the present study was trans-nerolidol (16\% of total essential oil). The present study showed substances similar to those found in other involving leaves of the P. umbellata essential oil collected in Sao Paulo State, Brazil (Martins et al., 1998; Luz et al., 1999; Moraes et al., 2004).

The variation in the concentration of the major substance, trans-nerolidol, which is an isoprene unit of phenylpropanoid 4-nerolidylcathecol-4NC (Bergamo et al., 2005), is important because nowadays it is a target of cosmetics industries due to its high antioxidant activity providing protection against skin problems induced by sun radiation (Ropke et al., 2003) and it must be clearified the concentration. The concentration of phenylpropanoid 4-nerolidylcathecol-4NC increased with light and was higher in plants cultivated under full sun. This information is important for future studies on the production of $P$. umbellata aiming to higher production of 4-NC.

We conclude that shade affects the production of the essential oil of $P$. umbellata, as well as the essential oil composition. For this reason, it is recommended that $P$. umbelatta have to be grown in shaded environments so as to favor the maximum production of its essential oil. In the second harvest the maximum relative proportion of the essential oil should be evaluated depending on the interest in a specific type of chemical constituent.

\section{Acknowledgements}

To CAPES, for supporting this research.

\section{References}

Adams, R.P. 1995. Identification of Essential Oil Components by Gas Chromatography/Mass Spectroscopy. Allured, Carol Stream, IL, USA.

Bergamo, D.C.B.; Massuo, K.; Bolzani, V.S.; Furlan, M. 2005. Biosynthetic origins of the isoprene units of 4-Nerolidylcatechol in Pothomorphe umbellata. Journal of the Brazilian Chemical Society 16: 1406-1409.

Di Stasi, L.C.; Santos, E.M.G.; Santos, C.M. 1989. Medicinal Plants of the Amazon. Edusp, São Paulo, SP, Brazil. (in Portuguese). 
Figueiredo, R.O.; Delachiave, M.E.A.; Ming, L.C. 2006. Plant growth regulators on biomass production and content of essential oils in Cymbopogon citratus (DC.) Stapf, in different seasons. Revista Brasileira de Plantas Medicinais 8: 31-35. (in Portuguese with abstract in English).

Giacometti, D.C. Condiments em Aromatic Herbs. 1989. Nobel, São Paulo, SP, Brazil. (in Portuguese).

Halva, S.; Cracker, L.E.; Simon, J.E. 1992. Light levels, growth and essential oil in dill (Anethum graveolens). Journal of Herbs, Spices \& Medicinal Plants 1: 47-57.

Kapur, K.K.; Vashit, V.N.; Atal, C.K. 1982. Variability and utilization studies on Eucalyptus citriodora Hook. Grown in India. p. 603-606. In: Atal, C.K.; Kapur, B.M., eds. Cultivation and utilization of aromatic plants. Regional Laboratory Council of Scientific and Industrial Research, Jammu-Tawi, India.

Li, Y.; Cracker, L.E.; Potter, T. 1996. Effect of light level on essential oil of sage (Salvia officinalis) and thyme (Thymus vulgaris). Acta Horticulturae 426: 419-426.

Luz, A.I.R.; Da-Silva, J.D.; Zoghbi, M.G.B.; Andrade, E.H.A.; Da-Silva, M.H.L.; Maia J.G.S. 1999. Volatile constituents of Brazilian Piperaceae: the oils of Pothomorphe umbellata and Pothomorphe peltata. Journal of Essential Oil Research 11: 479481.

Marchese, J.A.; Figueira, G.M. 2005. Use of technologies before and after harvest and good agricultural practices in the production of medicinal and aromatic plants. Revista Brasileira de Plantas Medicinais 7: 86-96. (in Portuguese, with abstract in English).

Marchese, J.A.; Mattana, R.S.; Ming, L.C.; Broetto, F.; Vendramini, P.F.; Moraes, R.M. 2008. Light stress responses of gas exchange and antioxidant enzyme contents in pariparoba [Pothomorphe umbellata (L.) Miquel.] plants. Photosynthetica 46: 501-505.
Mattana, R.S.; Ming, L.C.; Marchese, J.A.; Marques, M.O.M. 2006. Biomass production in plants of Pothomorphe umbellata (L.) Miq. submitted to differents shade levels. Revista Brasileira de Plantas Medicinais 8: 83-85.

Martins, A.P.; Salgueiro, L.; Vila, R.; Tomi, F.; Cañigueral, S.; Casanova, J.; Proença da Cunha, A.; Adzet, T. 1998. Essential oils from four Piper species. Phytochemistry 49: 2019-2023.

Mclafferty, F.W.; Stauffer, D. 1989. The Wile/NBS Registry of Mass Spectral Data. John Wiley, New York, NY, USA.

Moraes, M.S.; Akissue, M.K.; Oliveira, F.; Akissue, G. 1984. Chromatographic characterization of drug and fluid extract of Pothomorphe umbellata (L.) (Miq.). Anais de Farmácia e Química de São Paulo 24: 1-9. (in Portuguese).

Moraes, M.S.; Marques, M.O.M.; Machado, S.R. 2004. Essential oil of the Pothomorphe peltata (L.) Miq. Journal of Essential Oil Research 16: 15-16.

Nascimento, M.E.; Vilhena-Potiguara, V.C.R. 1999. Anatomical aspects of the vegetative organs of Piper hispidinervum C DC. (Piperaceae) and their secretory structures. Boletim do Museu do Pará Emílio Goeldi 15: 39-104. (in Portuguese).

Ropke, C.D.; Meirelles, R.R.; Silva, V.V.; Sawada, T.C.H.; Barros, S.B.M. 2003. Pothomorphe umbellata extract prevents a-tocoferol depletion aftes UV-irradiation. Photochemistry and Photobiology 78: 436-439.

Salatino, A.; Silva, J.B. 1975. Anatomy and essential oil of the Piper regnellii (Miq.) C.DC. var. Regnellii. Boletim de Botânica Universidade de São Paulo 3: 95-106 (in Portuguese).

Saleh, M. 1973. Effects of light upon quantity and quality of Matricaria chamomila oil. Planta Medica 24: 337-340.

Received September 02, 2008

Accepted March 31, 2010 